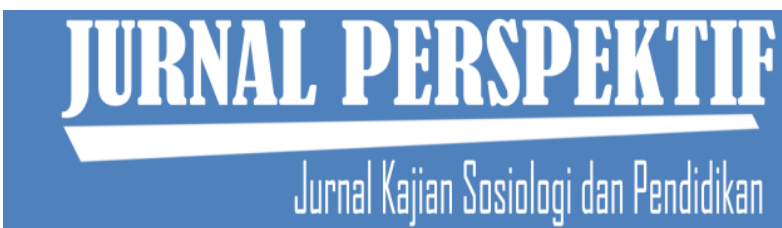

Jurnal Perspektif: Jurnal Kajian Sosiologi dan Pendidikan Vol. 3 No. 2 Tahun 2020

http://perspektif.ppj.unp.ac.id

Email: perspektif@ppj.unp.ac.id

ISSN: 2622-1748 (Online), 2684-902X (Print)

DOI: http://dx.doi.org/10.24036/perspektif.v3i2.249

\title{
Stereotipe Terhadap Perempuan Penyandang Disabilitas di Kota Padang (Studi Pada Perempuan Penyandang Disabilitas Daksa di DPC PPDI Kota Padang)
}

\author{
Dian Lestari ${ }^{1}$, Wirdanengsih Wirdanengsih ${ }^{2}$ \\ ${ }^{1,2}$ Universitas Negeri Padang \\ Email: dianlestari424@gmail.com, wirdanengsih69@yahoo.com
}

\begin{abstract}
Abstrak
Penelitian ini bertujuan untuk melihat dampak stereotipe masyarakat terhadap perempuan penyandang disabilitas daksa. Teori yang digunakan untuk menganalisis penelitian ini adalah teori konstruksi oleh Peter L.Berger dan Thomas Lukmann dengan menggunakan perspektif gender. Metode yang digunakan dalam penelitian ini ialah pendekatan kualitatif dengan tipe deskriptif dan dalam pemilihan informan menggunakan teknik snowball sampling. Data diperoleh dari observasi, wawancara mendalam, dan dokumentasi dengan teknik analisis data dari Miles dan Huberman. Hasil penelitian menunjukkan dampak dari stereotipe terhadap perempuan penyandang disabilitas daksa yaitu dampak positif dan dampak negatif. Dampak positif yaitu sebagai: (a) motivasi, sedangkan dampak negatif yaitu terdiri dari: (a) sulit memperoleh pekerjaan, (b) tidak dapat ikut serta dalam kegiatan di lingkungan masyarakat, (c) sulit mengikuti pendidikan formal (d) korban kekerasan seksual (e) korban bullying, (f) tertutup, (g) subjektif dan pembatasan dalam pergaulan, (h) tidak percaya diri atau minder dan (i) sulit mendapatkan dan mempertahankan pasangan.
\end{abstract}

Kata Kunci: Disabilitas daksa, Gender, Masyarakat, Perempuan, Stereotipe

This research aims to look at the impact of community stereotypes on women with physical disabilities. The theory used to analyze this research is the theory of construction by Peter L.Berger and Thomas Lukmann using a gender perspective. The method used in this research is a qualitative approach with descriptive type and in the choice of informants using snowball sampling techniques. Data obtained from observations, in-depth interviews, and documentation with data analysis techniques from Miles and Huberman. The results showed that there are positive and negative impacts of stereotypes on women with disabilities. Positive impact is: (a) motivation, while negative impacts consist of: (a) difficult to get a job, (b) unable to take part in activity in the community, (c) difficult to attend formal education $(d)$ victims of sexual violence $(e)$ victims of bullying, $(f)$ closed, $(g)$ subjective and socially restricted, $(h)$ unconfident or inferior and (i) difficult to find and keep up partners.

Keywords: Physical disability, Gender, Society, Stereotypes, Women

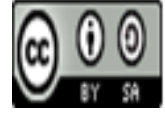

\begin{tabular}{|l|l|l} 
Received: April 22, 2020 & Revised: May 2, 2020 & Available Online: May 4, 2020 \\
\hline
\end{tabular} 
Dian Lestari, Wirdanengsih Wirdanengsih Stereotipe Terhadap Perempuan Penyandang Disabilitas di Kota Padang (Studi Pada Perempuan Penyandang Disabilitas Daksa di DPC PPDI Kota Padang)

\section{Pendahuluan}

Stereotipe merupakan pelabelan terhadap pihak atau kelompok tertentu yang merugikan pihak lain dan menimbulkan ketidakadilan (Narwoko, Suyanto, \& Dwi, 2009). Stereotipe cenderung menampilkan gagasan keliru (false idea) yang menimbulkan penilaian negatif atau bahkan bersifat merendahkan orang lain. Stereotipe memiliki aspek bagian seperti: stereotipe pekerjaan, stereotipe pendidikan, stereotipe antar etnis, dan stereotipe gender. Stereotipe didasarkan pada penafsiran yang dihasilkan atas dasar cara pandang dan latar belakang budaya, dihasilkan dari komunikasi dengan pihak lain dan bukan dari sumbernya langsung (Saguni, 2014).

Convention on the Elimination of All Forms of Discrimination Against Women (CEDAW), atau yang lebih dikenal dengan konvensi perempuan sudah berpijak pada kondisi bahwa meskipun sudah ada berbagai instrument internasional mengenai Hak Asasi Manusia (HAM) dimana perempuan termasuk dalam subjek yang diatur, namun pada kenyataannya diberbagai belahan dunia, perempuan sering menjadi warga negara yang terpinggirkan (Rahakbauw \& Salakory, 2017). Tidak terkecuali dengan perempuan penyandang disabilitas di Kota Padang yang sejatinya telah mendapatkan perlindungan hukum untuk kehidupannya dalam masyarakat. Data dari Dewan Pimpinan Cabang yang secara general mewadahi semua penyandang disabilitas se-Kota Padang menunjukkan jumlah penyandang disabilitas di DPCPPDI (Dewan Pimpinan Cabang-Persatuan Penyandang Disabilitas) Kota Padang adalah 671 orang laki-laki dan 452 orang perempuan dengan jenis keterbatasan yang berbeda. Dari data perempuan disabilitas yang ada, terdapat 200 orang grahita, 19 orang tuna netra, 137 orang tuna rungu dan wicara, 3 orang autis, 15 orang menyandang status tuna ganda dan 78 orang tuna daksa.

Idealnya berdasarkan undang-undang no 8 tahun 2016 tentang penyandang disabilitas, terdapat hak-hak mereka yang tertuang pada pasal 5 yaitu: a) hak hidup, b) bebas dari stigma, c) privasi, d) keadilan dan perlindungan, e) pendidikan, f) pekerjaan, kewirausahaan, koperasi, g) kesehatan, h) politik, i) keagamaan, j) keolahragaan, k) kebudayan dan pariwisata, l) kesejahteraan sosial, m) aksesibilitas, n) pelayanan publik, o) perlindungan dari bencana, p) habilitasi dan rehabilitasi, q) konsesi, r) pendataan, s) hidup secara mandiri dan dilibatkan dalam masyarakat, t) berekspresi, berkomunikasi dan memperoleh informasi, $u$ ) berpindah tempat dan kewarganegaraan, v) bebas dari tindakan diskriminasi, penelantaran, penyiksaan, dan eksploitasi.

Namun, realitasnya perempuan penyandang disabilitas mendapatkan diskriminasi berlapis berupa pemberian stereotipe atau pandangan yang belum tentu kebenarannya. Keyakinan terhadap perempuan yang notabenenya sudah dianggap oleh masyarakat sebagai seseorang yang lemah, pasif dan berkedudukan rendah dibandingkan laki-laki, tentu perempuan penyandang disabilitas secara otomatis mendapatkan stereotipe ganda (double stereotipe) dari masyarakat mengenai kekurangan, kelemahan dan ketidakberdayaan dalam menopang hidupnya. Apalagi seorang perempuan dengan status penyandang disabilitas daksa, yaitu seseorang dengan keadaan rusak atau terganggunya fungsi bentuk tulang, otot dan sendi yang disebabkan oleh penyakit, kecelakaan atau dapat juga disebabkan oleh pembawaan sejak lahir dan mereka memerlukan alat bantu (tools) untuk mempermudah mereka dalam bergerak (Utami, Raharjo, \& Apsari, 2018). Hal ini menjadi menarik ketika ada ruang gerak yang terbatas bagi mereka dalam melakukan aktivitas akibat kekurangan fungsi gerak pada tubuh ternyata menimbulkan anggapan dan pandangan negatif dari masyarakat disekeliling mereka, sehingga berdampak terhadap keberlangsungan kehidupannya ditengah-tengah masyarakat. 
Dian Lestari, Wirdanengsih Wirdanengsih Stereotipe Terhadap Perempuan Penyandang Disabilitas di Kota Padang (Studi Pada Perempuan Penyandang Disabilitas Daksa di DPC PPDI Kota Padang)

Penelitian yang relavan dengan penelitian ini dilakukan oleh Choriana Nur Hamidah pada tahun 2017, penelitiannya berjudul "Pengaruh Stereotip Gender Terhadap Partisipasi Penyandang Disabilitas Netra Di Lingkungan Keluarga dan Masyarakat (Anggota Dewan Pimpinan Daerah Ikatan Tuna Netra Muslim Indonesia Kota Yogyakarta)" dengan menggunakan metode penelitian kualitatif (Hamidah, 2017). Penelitiannya membahas mengenai stereotipe yang diterima oleh penyandang disabilitas netra dilingkungan keluarga, masyarakat dan dunia kerja. Hasilnya ternyata didalam keluarga mereka dibatasi untuk melakukan kerja atau aktivitas yang dirasa tidak mampu dilakukan, mereka yang disabilitas didalam keluarga tidak menjadi prioritas utama, dan mereka dilarang untuk menikah sesama tuna netra. Didalam masyarakat sekitarnya mereka tidak mendapat stereotipe tetapi masyarakat lain lah yang memberikan stereotipe, begitu pula dengan dunia kerja kaum disabilitas netra belum memperoleh perhatian dalam masyarakat. Hasil lain dalam penelitian ini yaitu pengaruh dari stereotipe yang diterima oleh penyandang disabilitas netra seperti membatasi partisipasi dalam keluarga, tidak melibatkan penyandang tuna netra dalam kegiatan masyarakat dan memiliki hambatan dalam mendapatkan pekerjaan.

Penelitian lain dilakukan oleh Safira Amalia Nuranisa pada tahun 2018, penelitian tersebut berjudul "Stereotip Masyarakat Terhadap Penyandang Disabilitas Dalam Dunia Kerja (Studi Kasus Pada Pekerja Penyandang Disabilitas di Enhai Bandung)", dengan menggunakan jenis penelitian kualitatif (Nuranisa, 2016). Penelitian ini mengkaji tentang stereotipe masyarakat terhadap para pekerja penyandang disabilitas dengan melihat faktor munculnya stereotipe dan akibat dari stereotipe di Enhai Hotel Bandung. Hasilnya stereotip memunculkan perlakuan diskriminasi dan ketidakadilan dalam dunia kerja. Penelitian oleh Yohanes Subasno, tahun 2016 dalam jurnalnya yang berjudul "Masalah Disabilitas dan Sosial Kemasyarakatan Di Malang Raya", dengan menggunakan pendekatan kuantitatif dengan hasil penelitian masih ditemukan persepsi dan perlakuan yang berbeda terhadap penyandang disabilitas (Subasno, 2016). Keberadaan penyandang disabilitas dipandang kurang bisa memberikan peran lebih dalam kegiatan yang membutuhkan orang banyak, artinya masyarakat memberikan stereotipe kepada mereka bahwa tidak adanya partisipasinya mereka dalam masyarakat dianggap wajar sebagai bentuk dari ketidakmampuan mereka dalam bergaul dan bertindak didalam masyarakat.

\section{Metode Penelitian}

Penelitian ini dilakukan di DPC PPDI (Dewan Pimpinan Cabang Persatuan Penyandang Disabilitas Indonesia) Kota Padang. DPC PPDI merupakan suatu wadah yang menghimpun penyandang disabilitas laki-laki maupun perempuan dengan berbagai macam jenis keterbatasan.

Pendekatan yang digunakan adalah pendekatan kualitatif dengan tipe deskriptif yang menghasilkan data berupa kata tertulis atau lisan dari orang dan perilaku yang dapat diamati (Basrowi \& Suwandi, 2008). Pendekatan ini digunakan dengan maksud untuk memperoleh pemahaman tentang realitas yang terjadi dengan proses induktif. Realitas yang dipahami akan dianalisis dan menghasilkan data berupa penggambaran tentang dampak stereotipe terhadap perempuan penyandang disabilitas daksa. Pemilihan informan ditentukan berdasarkan teknik tertentu yang bertujuan untuk mendapatkan informasi sesuai dengan tujuan penelitian, oleh karena itu peneliti menggunakan teknik snowball sampling dimana terdapat DH (49 tahun) yaitu seorang perempuan penyandang disabilitas daksa sebagai informan utama. Jumlah informan dalam penelitian ini adalah 33 orang. Observasi yang dilakukan yaitu observasi 
Dian Lestari, Wirdanengsih Wirdanengsih Stereotipe Terhadap Perempuan Penyandang Disabilitas di Kota Padang (Studi Pada Perempuan Penyandang Disabilitas Daksa di DPC PPDI Kota Padang)

partisipatif, dimana didalam kegiatan penelitian peneliti bertindak sebagai pengamat dan juga sebagai partisipan. Peneliti mengamati sekaligus berpartisipasi secara aktif dalam kegiatan kelompok perempuan penyandang disabilitas untuk mendapatkan informasi yang akurat. Disamping itu peneliti juga melakukan wawancara mendalam (indepth interview) yaitu informasi diperoleh berdasarkan percakapan intensif dengan informan menggunakan pedoman wawancara atau catatan pemikiran yang berisi pertanyaan-pertanyaan mendalam (Sugiyono, 2016). Peneliti juga menggunakan studi dokumentasi berupa dokumen tertulis, arsip dan foto guna memperkuat hasil penelitian. Agar informasi yang diperoleh pada saat penelitian dapat bersifat akurat, valid, dan sah, maka dilakukan triangulasi data. Triangulasi data bertujuan untuk memeriksa keabsahan data yang diperoleh dengan memanfaatkan hal lain di luar data sebagai suatu pembanding. Analisis dalam penelitian kualitatif dilakukan secara interaktif dan terus menerus sampai diperoleh kejenuhan data, maka dari itu teknik analisis data yang digunakan dalam penelitian ini adalah teknik analisis data model Miles dan Huberman.

\section{Hasil dan Pembahasan}

Dari proses wawancara yang dilakukan dengan mewawancarai 33 orang informan yang terdiri dari 15 orang perempuan penyandang disabilitas daksa, 6 orang keluarga yang bersangkutan, 1 orang pengurus DPC PPDI Kota Padang, 1 orang pengurus HWDI (Himpunan Wanita Disabilitas Indonesia) Kota Padang, 8 orang masyarakat disekitar lokasi penelitian, 1 orang dari Dinas Sosial Kota Padang, dan 1 orang dari DP3AP2KB Kota Padang diketahui bahwa ada realitas dalam masyarakat tentang pemberian stereotipe kepada perempuan penyandang disabilitas daksa dan menimbulkan dampak bagi mereka. Perempuan penyandang disabilitas daksa yang menjadi informan adalah sebagai berikut:

Tabel 1. Daftar Informan Perempuan Penyandang Disabilitas Daksa di DPC PPDI Kota Padang

\begin{tabular}{cccc}
\hline No & Inisial Nama & Usia & Pendidikan \\
\hline 1 & SA & 22 tahun & Tamat SMA \\
\hline 2 & SW & 25 tahun & Tamat SMP \\
\hline 3 & AN & 28 tahun & Tamat S1 \\
\hline 4 & JA & 31 tahun & Tamat SMA \\
\hline 5 & SD & 32 tahun & Tamat SMA \\
\hline 6 & MW & 39 tahun & Tamat SMP \\
\hline 7 & LK & 40 tahun & Tamat SMK \\
\hline 8 & SV & 40 tahun & Tamat SD \\
\hline 9 & DA & 42 tahun & Tamat S1 \\
\hline 10 & EM & 43 tahun & Tamat SMA \\
\hline 11 & IN & 43 tahun & Tamat SD \\
\hline 12 & NY & 43 tahun & Tamat SMA \\
\hline 13 & SR & 44 tahun & Tamat SMA \\
\hline 14 & SY & 45 tahun & Tamat SMA \\
\hline 15 & DH & 49 tahun &
\end{tabular}

Sumber: Hasil observasi dan wawancara peneliti 
Dian Lestari, Wirdanengsih Wirdanengsih Stereotipe Terhadap Perempuan Penyandang Disabilitas di Kota Padang (Studi Pada Perempuan Penyandang Disabilitas Daksa di DPC PPDI Kota Padang)

Bentuk stereotipe yang diterima perempuan penyandang disabilitas daksa adalah 1) Tidak Mandiri, 2) Lemah dan Tidak Berdaya, 3) Orang yang Aneh, dan 4) Tidak Menarik. Pertama, perempuan penyandang disabilitas daksa dianggap tidak mandiri yang diartikan sebagai ketidakmampuan mereka untuk bertindak bebas dalam melakukan segala sesuatu sendiri atau masih sangat bergantung pada orang lain. Tidak mandiri pada perempuan penyandang disabilitas daksa dilihat dari ketidakmampuan mereka untuk mengurus diri sendiri, mengurus rumah tangga dan tidak mampu bekerja tanpa bantuan orang lain. Kedua, lemah dan tidak berdaya. Budaya patriarki didalam masyarakat menimbulkan bias gender sehingga meletakkan posisi perempuan lebih rendah dibandingkan laki-laki. Perempuan penyandang disabilitas daksa mendapatkan dua kali lipat stereotipe tentang kelemahan dan ketidakberdayaan mereka untuk menjalani kehidupan yaitu sebagai seorang perempuan dan sebagai penyandang cacat. Ketiga, sebagai orang yang aneh. Adanya perbedaan yang mencolok dari segi fisik yang terlihat pada perempuan penyandang disabilitas daksa dipandang masyarakat sebagai suatu bentuk keanehan. Meskipun sebagian masyarakat tidak menunjukkan secara langsung respon terhadap keanehan tersebut, namun bagi mereka ketika orang lain melihat berulang kali dan memandang ke arah mereka maka hal itu dianggap menunjukkan bahwa mereka telah dianggap sebagai orang yang aneh. Keempat, tidak menarik. Perempuan di identikkan sebagai makhluk yang cantik dan penuh dengan keindahan, sebab itu di akui bahwa apa yang ditampilkan oleh mereka melalui tubuhnya adalah apa yang sesungguhnya ingin di lihat laki-laki. Namun, realita yang terjadi, anggapan masyarakat terhadap perempuan penyandang disabilitas daksa sangatlah berbeda. Mereka dipandang sebagai orang yang tidak menarik, tidak cantik atau bahkan tidak proporsional untuk di jadikan pasangan.

Berdasarkan bentuk-bentuk stereotipe itu dapat dilihat dampak negatif yang ditimbulkan terhadap perempuan penyandang disabilitas daksa yaitu sebagai berikut:

\section{Sulit Memperoleh Pekerjaan}

Masyarakat memiliki standarisasi dalam pembagian kerja (division of labour) yang didasarkan pada jenis kelamin dan gender. Seorang perempuan yang di masyarakat telah mendapatkan posisi kedua dalam setiap bidang kehidupannya tentu perempuan disabilitas daksa pada akhirnya menempati urutan kesempatan paling belakang disetiap sektor kehidupan yang ada, termasuk dalam bidang pekerjaan.

Perempuan penyandang disabilitas daksa yang memiliki keterbatasan pada ruang geraknya baik itu pada kaki atau tangan dianggap tidak mampu melakukan pekerjaannya secara mandiri. Padahal dalam usaha pencapaian taraf hidup, kualitas hidup dan martabat manusia, hendaknya angkatan kerja perempuan juga diberi peluang yang sama seperti hal nya angkatan kerja laki-laki (Selinaswati, 1990). Tidak jauh berbeda dengan perempuan normal, perempuan penyandang disabilitas daksa sejatinya juga butuh pekerjaan dalam rangka pemenuhan kebutuhan dan peningkatan kualitas dirinya. Meskipun telah tertuang pada kebijakan publik Kota Padang No.3 Tahun 2015 pasal 29 dan pasal 35 tertulis bahwa adanya pemberian kesempatan kepada penyandang disabilitas untuk memperoleh pekerjaan dan mempekerjakan 1 orang penyandang disabilitas dari 100 orang pegawai yang ada di BUMN, BUMD atau badan usaha lainnya. Namun, perempuan penyandang disabilitas daksa masih kesulitan dalam memperoleh pekerjaan yang layak.

\section{Tidak Dapat Ikut Serta dalam Kegiatan di Lingkungan Masyarakat}

Kondisi fisik yang berbeda dengan orang normal pada umumnya memunculkan permasalahan yaitu terhambatnya partisipasi perempuan penyandang disabilitas daksa di dalam masyarakat. Laki-laki dan perempuan memiliki batas ruang gerak yang berbeda, jika laki-laki 
Dian Lestari, Wirdanengsih Wirdanengsih Stereotipe Terhadap Perempuan Penyandang Disabilitas di Kota Padang (Studi Pada Perempuan Penyandang Disabilitas Daksa di DPC PPDI Kota Padang)

diberikan kebebasan dalam menjalankan aktivitasnya maka perempuan memiliki batasanbatasan tertentu yang sudah diatur, apalagi perempuan penyandang disabilitas daksa. Batasan mereka bukan hanya terletak pada kekurangan fisik saja, namun dengan adanya anggapan tentang ketidakmandirian mereka juga berakibat pada sulitnya mereka berperan aktif dalam masyarakat.

\section{Sulit Mengikuti Pendidikan Formal}

Pendidikan merupakan sebuah usaha terencana untuk menciptakan potensi yang dimiliki individu agar mempunyai kemampuan spiritual, pengendalian diri, keagamaan, kepribadian dan kecerdasan yang berguna bagi diri, masyarakat, bangsa dan negara. Pendidikan sangat dibutuhkan dalam rangka peningkatan kualitas sumber Daya Manusia (SDM) agar manusia itu mampu menjadi individu yang tepat dalam mengambil keputusan, mampu merencanakan masa depan dengan baik, dapat berinteraksi dengan baik dengan lingkungan dan mampu menghadapi segala perubahan zaman. Melihat kedudukan dan peranan strategis dari seorang perempuan, sudah sewajarnya dalam proses pendidikan mereka mendapatkan tempat yang sewajarnya pula (Sumar, 2015). Namun berbeda dengan perempuan penyandang disabilitas daksa, konsep baku peran gender yang telah membedakan peran laki-laki dan perempuan memungkinkan perempuan berperan hanya di wilayah domestik yakni sebagai pengurus rumah tangga sementara laki-laki di wilayah publik sebagai kepala keluarga dan pencari nafkah utama (Zaduqisti, 2009). Jika, perempuan telah dianggap sebagai kaum yang tidak memerlukan pendidikan karena pada ujungnya akan mengurus urusan domestik, maka perempuan penyandang disabilitas daksa yang memiliki hambatan dan dianggap tidak mampu melakukan segala sesuatu sendiri tentu menjadi sulit untuk mendapatkan bangku pendidikan, terutama pendidikan formal.

\section{Korban Kekerasan Seksual}

Kerangka teori hukum berperspektif perempuan (feminist legal theory) mengungkapkan cara perempuan diposisikan dan diberikan peran sangat ditentukan oleh sistem sosial yang mengatur hubungan antar orang dan kelompok di masyarakat itu sendiri, Hal itu terlihat dari bagaimana pencitraan perempuan sebagai objek seks laki-laki yang berimplikasi pada kehidupan perempuan yang sering menghadapi kekerasan, pemaksaan, dan penyiksaan fisik, psikis, dan bahkan sebagai korban kekerasan seksual (Abdullah, Dzuhayatin, \& Pitaloka, 2001). Hal ini terjadi karena tata nilai yang meletakkan perempuan sebagai second class citizens. Perempuan sebagai seseorang yang dipandang tidak berdaya dan lemah apalagi perempuan dengan status penyandang disabilitas sangat rawan akan perlakuan kekerasan seksual dari orang lain (Haryono, Kinasih, \& Mas'udah, 2013). Kekerasan seksual terutama pemerkosaan terhadap perempuan penyandang disabilitas seringkali terjadi terutama di Kota Padang diakibatkan oleh anggapan masyarakat terutama laki-laki bahwa mereka adalah kelompok yang lemah dan tidak berdaya.

\section{Korban Bullying}

Kondisi fisik yang tidak sempurna pada perempuan penyandang disabilitas daksa memunculkan permasalahan yaitu mereka seringkali mendapatkan perlakuan yang tidak layak oleh orang-orang disekeliling mereka. Menurut Subini keterbatasan fisik yang dimiliki penyandang disabilitas daksa/fisik memungkinkan mereka diganggu, dicela, di olok-olok secara verbal maupun dengan perilaku yang disebut bullying (Ningsih, 2019). Perempuan penyandang disabilitas daksa didalam masyarakat dikucilkan, diremehkan, dan tidak sedikit dari mereka yang di olok-olok karena kekurangan yang mereka miliki, bahkan terjadi 
Dian Lestari, Wirdanengsih Wirdanengsih Stereotipe Terhadap Perempuan Penyandang Disabilitas di Kota Padang (Studi Pada Perempuan Penyandang Disabilitas Daksa di DPC PPDI Kota Padang)

pemaksaan secara fisik maupun psikis terhadap mereka yang berakibat pada munculnya perasaan tertekan dan trauma.

\section{Tertutup}

Perempuan penyandang disabilitas daksa yang cenderung bergantung pada orang lain membuat mereka dipandang lebih rendah sehingga mereka tertutup dan menarik diri dari pergaulan. Mereka tidak membuka diri terhadap dunia luar, sulit berinteraksi dengan orang lain dan tidak nyaman dengan kerumunan.

\section{Subjektif dan Pembatasan dalam Pergaulan}

Perempuan penyandang diabilitas daksa bersikap subjektif, ketika ada orang yang menjumpai mereka, maka mereka terlebih dahulu akan melihat orang tersebut baik atau tidak atau apakah mereka tidak akan melukai perasaan mereka. Jika "iya" mereka langsung memberikan jarak atau batasan dan bahkan sama sekali tidak ingin saling mengenal, begitupun sebaliknya jika mereka nyaman maka akan ada sikap menerima dan terciptanya interaksi lebih lanjut.

\section{Tidak Percaya Diri atau Minder}

Rasa percaya diri merupakan hal yang harus dimiliki oleh seseorang, tanpa rasa percaya diri seseorang tidak akan mampu untuk melakukan aktifitas atau kegiatan didalam kehidupannya. Begitu pula dengan seorang perempuan, mereka sangat memerlukan rasa percaya diri untuk menampilkan citra yang ada pada dirinya, namun stereotipe ganda yang diterima oleh perempuan penyandang disabilitas daksa malah menimbulkan rasa tidak percaya diri mereka untuk bergaul dengan lingkungan masyarakat. Mereka merasa tidak pantas, tidak berani memulai percakapan dengan orang lain, takut jika orang-orang menolak atau tidak menyukai keberadaannya dan merasa orang lain selalu memandang sisi kekurangan dan kelemahan mereka terutama sebagai perempuan yang seharusnya dipandang menarik di mata laki-laki

\section{Sulit Mendapatkan dan Mempertahankan Pasangan}

Perempuan disabilitas daksa yang dipandang sebagai orang yang tidak menarik dari segi fisik berdampak pada sulitnya mereka mendapatkan pasangan atau mempertahankan rumah tangganya. Apalagi di Sumatera Barat ada istilah yang menyebutkan "condong mato nan ka rancak, condong salero nan ka lamak" yang bermakna bahwa manusia cenderung lebih tertarik pada yang cantik dan menarik. Artinya, kekurangan perempuan penyandang disabilitas daksa yang disertai dengan anggapan-anggapan masyarakat tentang ketidakmampuan dan tidak menariknya mereka memunculkan penolakan masyarakat khususnya pada saat mencari pasangan, sehingga kecenderungan yang terjadi adalah perempuan penyandang disabilitas daksa menikah dengan sesama mereka atau dengan penyandang disabilitas lainnya.

Selain dampak negatif tersebut pemberian stereotipe negatif kepada perempuan penyandang disabilitas daksa juga dapat memberikan dampak positif yaitu sebagai suatu bentuk motivasi, anggapan masyarakat yang diterima dijadikan sebagai pendorong untuk menunjukkan kemampuan dan eksistensi diri mereka di tengah-tengah masyarakat. Cara untuk merubah anggapan itu ditunjukkan melalui pembuktian kesuksesan dan berkarya baik itu dalam berumah tangga, finansial maupun pendidikan.

Berdasarkan hasil penelitian tersebut maka peneliti menganalisis dampak stereotipe terhadap perempuan penyandang disabilitas daksa menggunakan teori konstruksi sosial Peter L.Berger dan Thomas Lukmann dengan perspektif gender. Peter L.Berger dan Thomas Luckmann menyatakan bahwa kenyataan merupakan hasil dari konstruksi sosial (Turner, 
Dian Lestari, Wirdanengsih Wirdanengsih Stereotipe Terhadap Perempuan Penyandang Disabilitas di Kota Padang (Studi Pada Perempuan Penyandang Disabilitas Daksa di DPC PPDI Kota Padang)

2012). Teori Konstruksi sosial menjelaskan bahwa terdapat hubungan dialektika antara diri (self) dan dunia sosiokultural dan hubungan tersebut berlangsung secara simultan melalui tiga momen yaitu eksternalisasi, objektivikasi dan internalisasi. Ia memandang bahwa kenyataan yang ada dibangun secara sosial, dalam artian individu telah membangun masyarakat. Masyarakat adalah produk individu dan individu merupakan hasil dari masyarakat, maka individu bukanlah konsep yang dapat dipisahkan dengan masyarakat itu sendiri.

Seseorang dalam kehidupan sehari-hari akan menampilkan diri sebagai kenyataan yang ditafsirkan oleh masyarakat. Hal tersebut mengantarkan kita pada suatu pemahaman tentang "kenyataan" dan "pengetahuan" yang lahir dari kontruksi sosial sangat dipengaruhi oleh pemahaman individu yang didasarkan pada kebiasaan (habitus) dan cadangan pengetahuan (stock of knowledge) (Sulaiman, 2016). Dilihat dari perspektif gender maka konstruksi sosial dan kultural masyarakat yang sejatinya telah membedakan peran perempuan dan laki-laki mengakibatkan adanya stereotipe atau pandangan berlipat terhadap perempuan penyandang disabilitas daksa. Apa yang dikonstruksikan terhadap orang lain tidak selalu menimbulkan sikap yang baik pada mereka, begitu pula dengan hasil konstruksi pada kelompok perempuan penyandang disabilitas daksa yaitu sebagai seseorang cenderung dijauhi, dikucilkan dan dipinggirkan dari kelompok yang tidak bisa menerima mereka (Tiarasari \& Pujihartati, 2018).

Maka berdasarkan penjelasan tersebut hubungan antara diri perempuan penyandang disabilitas daksa dengan dunia sosio-kultural (masyarakat) tersebut berlangsung melalui tiga momen yaitu eksternalisasi, objektivikasi dan internalisasi.

Pertama, eksternalisasi yang berkaitan dengan bagaimana persepsi orang tentang dunia luarnya. Masyarakat memandang bahwa perempuan penyandang disabilitas daksa itu adalah orang yang tidak mandiri, lemah dan tidak berdaya, orang yang aneh dan tidak menarik. Persepsi ini muncul dari dua hal pertama, konsep bias gender antara laki-laki dan perempuan yang menempatkan mereka pada posisi kelas dua dalam masyarakat, dan yang kedua adalah dari anggapan dan keyakinan individu-individu tertentu yang sudah tertanam lama dan dijadikan keyakinan bersama yang dalam hal ini masyarakat menjadi produk manusia (society is a human product).

Kedua, objektivikasi atau kesadaran dari hasil eksternalisasi telah termanifestasikan dalam masyarakat dan membentuk suatu realitas. Disaat perempuan penyandang disabilitas daksa mencoba keluar dari jurang keterbatasannya, institusi terkait yang dalam hal ini adalah masyarakat tidak mendukung langkah positif yang mereka lakukan, artinya masyarakat justru memberikan pandangan-pandangan sehingga gerak perempuan penyandang disabilitas semakin terbatas. Saat mereka ingin keluar dari anggapan selaku perempuan yang dipandang lemah dan tidak berdaya malah mereka diberikan double stereotipe yang berakibat pada semakin terbatasnya ruang gerak mereka, Seperti semakin sulitnya memperoleh pekerjaan, memperoleh pendidikan dan kesulitan dalam berpartisipasi di kegiatan masyarakat.

Ketiga, internalisasi dimana masuknya pengetahuan dan kesadaran baru ke dalam tatatanan individu yang digunakan untuk memetakan dunia luar. Dari proses eksternalisasi dan objektivikasi yang telah terjadi menyebabkan perempuan penyandang disabilitas daksa mendapatkan kesadaran dan pemahaman tentang realitas diluar kesadarannya. Ia berusaha memahami realitas objektif disekelilingnya dan berusaha memahami serta memberikan penilaian tersendiri tentang pemberian stereotipe terhadap dirinya. 
Dian Lestari, Wirdanengsih Wirdanengsih

Stereotipe Terhadap Perempuan Penyandang Disabilitas di Kota Padang

(Studi Pada Perempuan Penyandang Disabilitas Daksa di DPC PPDI Kota Padang)

\section{Kesimpulan}

Keberadaan perempuan penyandang disabilitas daksa yang sejatinya sudah dijamin hakhak nya dalam undang-undang ternyata masih banyak ditemukan permasalahan tentang keberadaan mereka didalam masyarakat salah satunya yaitu tentang pemberian stereotipe kepada mereka. Pemberian stereotipe itu memberikan dampak terhadap mereka dan menjadi hambatan dalam aktivitas mereka didalam kehidupan bermasyarakat. Bentuk-bentuk stereotipe yang mereka terima yaitu 1) Tidak Mandiri, 2) Lemah dan Tidak Berdaya, 3) Orang yang Aneh, dan 4) Tidak Menarik. Dari stereotipe itu muncul dampak bagi perempuan penyandang disabilitas daksa berupa dampak positif dan dampak negatif. Dampak positif yaitu sebagai: (a) motivasi, sedangkan dampak negatif yaitu terdiri dari: (a) sulit memperoleh pekerjaan, (b) tidak dapat ikut serta dalam kegiatan di lingkungan masyarakat, (c) sulit mengikuti pendidikan formal (d) korban kekerasan seksual (e) korban bullying, (f) tertutup, (g) subjektif dan pembatasan dalam pergaulan, (h) tidak percaya diri atau minder (i) sulit mendapatkan dan mempertahankan pasangan. Teori Konstruksi sosial menyatakan bahwa terdapat hubungan dialektika antara diri (self) dan dunia sosiokultural dan hubungan tersebut berlangsung secara simultan melalui tiga momen yaitu eksternalisasi, objektivikasi dan internalisasi. Kenyataan yang ada tentang pemberian stereotipe kepada perempuan penyandang disabilitas daksa dibangun secara sosial, dalam artian individu telah membangun masyarakat. Masyarakat adalah produk individu dan individu merupakan hasil dari masyarakat, maka individu bukanlah konsep yang dapat dipisahkan dengan masyarakat itu sendiri. Perspektif gender melihat konstruksi sosial dan kultural masyarakat sejatinya telah membedakan peran perempuan dan laki-laki dan berakibat pada munculnya stereotipe atau pandangan berlipat terhadap perempuan penyandang disabilitas daksa. Hasil dari konstruksi pada kelompok perempuan penyandang disabilitas daksa tersebut adalah munculnya poin-poin stereotipe yang berimplikasi pada kehidupan mereka di tengah-tengah masyarakat.

\section{Daftar Pustaka}

Abdullah, I., Dzuhayatin, S. R., \& Pitaloka, D. (2001). Bias Gender Dalam Penanganan Kasus Kekerasan Terhadap Perempuan Secara Litigatif. Populasi, 12(2), 45-75. https://doi.org/ 10.22146/jp. 12285

Basrowi, B., \& Suwandi, S. (2008). Memahami Penelitian Kualitatif. Jakarta: Rineka Cipta.

Hamidah, C. N. (2016). Pengaruh Stereotip Gender Terhadap Partisipasi Penyandang Disabilitas Netra Di Lingkungan Keluarga dan Masyarakat (Anggota Dewan Pimpinan Daerah Ikatan Tuna Netra Muslim Indonesia Kota Yogyakarta). Laporan Penelitian. UIN Sunan Kalijaga

Haryono, T. J. S., Kinasih, S. E., \& Mas'udah, S. (2013). Akses dan Informasi Bagi Perempuan Penyandang Disabilitas Dalam Pelayanan Kesehatan Reproduksi dan Seksualitas. Masyarakat, Kebudayaan dan Politik, 26(2), 65-79.

Narwoko, N., Suyanto, B., \& Dwi, J. (2009). Teks Pengantar dan Terapan. Jakarta: Kencana Media Group.

Ningsih, T. (2019). Resiliensi Penyandang Disabilitas Fisik yang Memiliki Pengalaman Bullying. Laporan Penelitian. Universitas Muhammadiyah Surakarta.

Nuranisa, S. A. (2016). Stereotip Masyarakat Terhadap Penyandang Disabilitas Dalam Dunia Kerja (Studi Kasus pada Pekerja Penyandang Disabilitas di Enhaii Hotel Bandung). IOSR Journal of Economics and Finance, 3(1), 56. https://doi.org/https://doi.org/10.3929/ethzb-000238666 
Dian Lestari, Wirdanengsih Wirdanengsih Stereotipe Terhadap Perempuan Penyandang Disabilitas di Kota Padang (Studi Pada Perempuan Penyandang Disabilitas Daksa di DPC PPDI Kota Padang)

Rahakbauw, N., \& Salakory, D. M. (2017). Perlindungan Sosial Bagi Perempuan Disabilitas (Studi di Himpunan Wanita Disabilitas Indonesia (HWDI) Maluku). Aristo, 6(1), 145. https://doi.org/10.24269/ars.v6i1.789

Saguni, F. (2014). Pemberian Stereotype Gender. Musawa, 6(2), 195-224.

Selinaswati, S. (1990). Analisis Gender Terhadap Keberadaan Pekerja Wanita di Departement Store (Studi Kasus Pramuniaga Matahari Dept. Store Pasar Raya Padang). Laporan Penelitian. Universitas Negeri Padang.

Subasno, Y. (2016). Masalah Disabilitas Dan Sosial Kemasyarakatan Di Malang Raya. Kateketik dan Pastoral, 1(2), 53-64.

Sugiyono. (2016). Metode Penelitian Kombinasi. Bandung: Alfabeta.

Sulaiman, A. (2016). Memahami Teori Konstruksi Sosial Peter L. Berger. Society, 4(1), 1522. https://doi.org/10.33019/society.v4i1.32

Sumar, W. T. (2015). Implementasi Kesetaraan Gender Dalam Bidang Pendidikan. Musawa, 7(1), 158-182. https://doi.org/10.1016/j.anuro.2003.10.003

Tiarasari, N., \& Pujihartati, S. H. (2018). KONSTRUKSI SOSIAL DIFABEL (Studi Fenomenologi Konstruksi Sosial Anak Difabel dalam Keluarga di Yayasan Pembinaan Anak Cacat Surakarta). Journal of Development and Social Change, 1(2), 1-104.

Turner, B. S. (2012). Teori Sosial (Dari Klasik Sampai Postmodern). Yogyakarta: Pustaka Pelajar.

Utami, E. O., Raharjo, S. T., \& Apsari, N. C. (2018). Aksesibilitas Penyandang Tunadaksa. Prosiding Penelitian dan Pengabdian kepada Masyarakat, 5(1), 83-87. https://doi.org/10.24198/jppm.v5i1.16962

Zaduqisti, E. (2009). Stereotipe Peran Gender dalam Pendidikan Anak. Jurnal Muwazah, 1(1), 73-82. https://doi.org/10.1016/j.expneurol.2015.03.020 